\title{
City lab a wdrażanie innowacji społecznych w mieście ${ }^{1}$
}

\section{Piotr Kopyciński*}

\begin{abstract}
Streszczenie: W niniejszym artykule podjęto się próby połączenia dwóch zagadnień: obecnej już od pewnego czasu problematyki innowacji społecznych z tematem, który pojawił się stosunkowo niedawno - city lab. Celem rozważań jest ukazanie istoty city lab w kontekście wdrażania innowacji społecznych. Dla jego realizacji autor dokonał analizy literatury przedmiotu oraz prezentacji studium przypadku. Artykuł rozpoczyna przegląd rozumienia innowacji społecznych. Następnie autor opisuje istotę city lab, wskazując przy tym na aktorów i pełnione przez nich funkcje. Wreszcie ukazano związki między koncepcją living lab a city lab oraz zastosowanie tej drugiej w Krakowie. W prezentowanym ujęciu city lab jest platformą służącą wdrażaniu innowacji społecznych. Te ostatnie dotyczą długookresowego planowania rozwoju miasta, realizowanego przy współudziale różnych interesariuszy, z dominującą rolą użytkowników (mieszkańców) miasta jako głównych innowatorów oraz władz lokalnych pilnujących realności i legalności proponowanych rozwiązań. Prezentowane podejście wydaje się warte propagowania zarówno przez przedstawicieli nauki, jak i decydentów publicznych.
\end{abstract}

Słowa kluczowe: city lab, living lab, innowacje społeczne.

\section{Wprowadzenie}

Rozumienie innowacji społecznych jest szeroko omawiane w literaturze przedmiotu, w tym również na łamach „Ekonomii Społecznej" [por. Moroń, Klimowicz, 2015]. Stąd też w pierwszej części artykułu zostanie dokonany jedynie skrótowy przegląd wybranych ujęć, niezbędny do podjęcia dalszych rozważań. Kluczowe będą bowiem kolejne części, ukazujące istotę city lab jako swoistej platformy służącej wdrażaniu innowacji społecznych w mieście.

Publikacja została przygotowana w projekcie "Kapitał ludzki jako podstawowy czynnik zakorzenienia globalnych usług biznesowych" nr: 059/WGAP-KGP/01/2018/S/8059, dofinansowanym z dotacji Ministerstwa Nauki i Szkolnictwa Wyższego dla Wydziału Gospodarki i Administracji Publicznej Uniwersytetu Ekonomicznego w Krakowie na utrzymanie potencjału badawczego.

\section{Rozumienie innowacji społecznych}

Myślenie w kategoriach innowacji społecznych można odnaleźć już w rozważaniach J. Schumpetera o "nowych kombinacjach" [Schumpeter, 1960], czy też pracach W.F. Ogburna, podkreślającego istnienie „luki kulturowej", która pojawiła się pomiędzy rozwojem technicznym i kulturowym, a rolę innowacji społecznych określającego jako możliwość zmniejszenia powyższej rozbieżności [Wiktorska-Święcka, Moroń, Klimowicz, 2015 , s. 23]. Jednak doprecyzowanie rozumienia tego sformułowania stało się przedmiotem zainteresowania badaczy stosunkowo niedawno. Konieczność prowadzenia tego typu badań zasygnalizowano w Deklaracji

\footnotetext{
* Piotr Kopyciński

Katedra Gospodarki Publicznej

Uniwersytet Ekonomiczny w Krakowie

ul. Rakowicka 16, 31-510 Kraków

e-mail: piotr.kopycinski@uek.krakow.pl
} 
Wiedeńskiej, przyjętej w ramach konferencji ICITI International Conference on Indicators and Concepts of Innovation w 2011 r. We wspomnianym dokumencie wskazano 14 priorytetowych kierunków badawczych z zakresu innowacji społecznych ${ }^{2}$. Sformułowanie to jest wykorzystywane do określenia nowych pomysłów (produktów, usług), które z jednej strony wychodzą naprzeciw oczekiwaniom społecznym (są bardziej efektywne niż rozwiązania alternatywne), a z drugiej przyczyniają się do poszerzenia możliwości współpracy i tworzenia więzi społecznych [Murray et al., 2010, s. 3]. Rozwiązania te są dobre dla całego społeczeństwa, zwiększają również jego zdolność do działania [The Young Foundation, 2012, s. 18]. Innowacje społeczne powstają na styku sektorów: publicznego, prywatnego i tzw. „trzeciego”, przy współudziale osób indywidualnych [BEPA, 2011, s. 9-10]. Podmiotami, które uczestniczą w procesie współtworzenia nowego rozwiązania mogą być: przedsiębiorstwa, obecni lub przyszli użytkownicy danego dobra, instytucje otoczenia biznesu i finansujące, instytucje naukowe czy też władze publiczne różnych szczebli.

Szukając odpowiedzi na pytanie o sens wdrażania innowacji społecznych można powołać się na autorów opracowania OECD, którzy wskazują, że głównym celem innowacji społecznych jest zaspakajanie nowych potrzeb, których nie gwarantuje rynek, oraz tworzenie nowych sposobów aktywizacji, poprzez zapewnienie miejsc pracy [OECD, 2011, s. 34]. W pierwszym rzędzie nie chodzi więc o osiąganie zysku w rozumieniu pozytywnego wyniku finansowego. Jak zauważa Mulgan [2012], innowacje społeczne są wdrażane w celu zaspakajania potrzeb społecznych i tworzenia relacji społecznych oraz możliwości współpracy, zwiększających zdolność społeczeństwa do działania. Warto w tym miejscu dodać, że szczególnym przypadkiem innowacji społecznych są innowacje miej- skie, które rozwiązują określone problemy na obszarach zurbanizowanych i powstają przy współudziale tzw. użytkowników miasta (czyli nie tylko mieszkańców, ale też np. dojeżdżających do pracy spoza miasta) [Kopyciński, 2018].

Powyższe postrzeganie innowacji jest odmienne od tego zaproponowanego w „Podręczniku Oslo" - wspólnej publikacji OECD i Eurostatu [2008] dotyczącej pomiaru działalności innowacyjnej, gdzie innowacje traktuje się jako rezultat działań przedsiębiorstwa w postaci nowych lub znacząco udoskonalonych produktów, procesów, zmian organizacyjnych i marketingowych. Jednocześnie należy podkreślić, że niniejsze oraz omawiane wcześniej stanowiska nie są podejściami wykluczającymi się: przykładowo, możemy mówić o zmianie produktowej, która jednocześnie będzie spełniała kryteria innowacji społecznej. W tych ujęciach mamy więc do czynienia z odmiennym punktem wyjścia do rozważań: innowacja jako problem indywidualny (przedsiębiorstwa) versus innowacja jako problem wspólnotowy, gdzie istotna jest współpraca zespołowa (collectivity).

\section{City lab}

Zanim przejdziemy do omawiania tytułowej kwestii, należy podkreślić, że istotną inspiracją dla city labs są living labs, z racji skoncentrowania się na tworzeniu innowacji ukierunkowanych na przyszłych użytkowników oraz ich angażowanie w sprawy funkcjonowania miasta [School, Kemp, 2016, s. 90]. Living lab można rozumieć jako platformę do wdrażania innowacji w otwartej formule (open innovation) [Paskaleva, 2014, s. 119], charakteryzującą się dobrowolnym zaangażowaniem użytkowników w proces wyłaniania się nowego rozwiązania [Nyström et al., 2014, s. 483]. Proces powstawania, testowania i wdrażania innowacji zachodzi w realnych warunkach (real-life environments), a nie w laboratorium badawczym [Almirall, 2009]. Przedsiębiorstwa czerpią więc

www.socialinnovation2011.eu (dostęp: 13.12.2012). 
pomysły na rozwój i wdrożenie innowacyjnych rozwiązań z otoczenia zewnętrznego.

Pojęcie living lab wydaje się dobrze opisywać zjawiska związane z otwartym powstawaniem innowacji na potrzeby przedsiębiorstwa. Jednak nie odzwierciedla procesu powstawania innowacji społecznych (miejskich). Tak rozumiane living lab posiada wprawdzie komponent partycypacyjny, ale zasadniczym celem takiej platformy jest zapewnienie zysku przedsiębiorstwu. Koncepcja ta nie do końca pasuje więc do partycypacyjnego planowania długookresowego rozwoju miasta, któremu przyświeca cel społeczny (publiczny). W takim ujęciu podstawowym decydentem są władze miasta (a nie kierownictwo przedsiębiorstwa), a współdecydującymi: mieszkańcy (użytkownicy) miasta, przedsiębiorstwa i jednostki naukowe. Nie ma jednego określenia na odróżnienie opisywanych tu procesów wspólnego rozwiązywania problemów miejskich od rozwiązywania problemów przedsiębiorstw. Używa się tu sformułowań urban living lab, urban lab, czy też city lab [por. np.: Scholl, Kemp, 2016, Voytenko et al., 2016; Urb@exp initiative], których znaczenie może się nieco różnić od siebie. W niniejszym opracowaniu autor będzie się posługiwał określeniem city lab, dla podkreślenie szczególnej roli władz publicznych [por. Scholl, Kemp, 2016, s. 90]. Możemy je rozumieć jako działania, w ramach których władze lokalne i inne podmioty są zaangażowane w procesy rozwiązywania wyzwań rozwojowych miast, do których należą np. rozwój terenów zdegradowanych czy też nieelastyczne regulacje [Urb@exp initiative]. Podobnie jak w przypadku living labs, oznacza to tworzenie innowacji w otwartej formule, gdzie duże znaczenie ma eksperymentowanie angażujące użytkowników, współtworzenie (co-creation) i wzajemne uczenie się, a testowanie odbywa się w realnych warunkach [ibidem]. Jest to więc specyficzny typ lab-u, w którym inicjatorem działań oraz ich istotnym uczestnikiem są władze miasta [Scholl, Kemp, 2016, s. 89].
School i Kemp [2016, s. 99-100] wymieniają cechy charakterystyczne city lab. Są nimi:

1. Hybrydowa forma organizacji zakładająca, że zarządzanie inicjatywą jest dzielone pomiędzy władze lokalne a innych uczestników. Taka formuła pozwala częściowo ominąć biurokratyczną logikę funkcjonowania władz lokalnych, co jest niezbędne dla powstawania innowacyjnych rozwiązań. Następuje integracja różnych środowisk miejskich skupionych wokół władz publicznych, jednostek naukowych, przedsiębiorców i mieszkańców.

2. Miejsce eksperymentowania z nowymi formami współzarządzania (governance) - inspiracja dla władz publicznych do zmian w procesach zarządzania miastem.

3. Współuczestniczenie i współdecydowanie przez różne podmioty, ze szczególnym znaczeniem władz lokalnych. Taki układ stanowi odpowiedź na coraz bardziej złożone wyzwania rozwojowe miast, których administracja lokalna nie jest w stanie samodzielnie rozwiązywać.

4. Wykorzystanie współtworzenia (co-creation) przy szukaniu nowych rozwiązań (eksperymentowaniu). Władze lokalne zazwyczaj nie angażują się w te eksperymenty, ale dostarczają (i modyfikują w procesie uczenia się) procedury, które mogą sprawić, że eksperyment zostanie z sukcesem wdrożony w mieście.

5. Rozwiązywanie złożonych problemów w sposób interdyscyplinarny, przy wykorzystaniu wiedzy z wielu dyscyplin.

Reasumując, city lab możemy rozumieć jako zespół działań inicjowanych przez władze publiczne, ukierunkowanych na długookresowe planowanie rozwoju miasta (cel publiczny). Są to innowacje planowane w otwartej formule (open innovation), w ramach eksperymentowania w realnych warunkach (a nie w zamkniętych laboratoriach) różnych podmiotów (przede wszystkim użytkowników miasta), przy szczególnym znaczeniu władz lokalnych. 


\section{City lab - aktorzy i ich role}

W przypadku city lab możemy mówić o obecności tych samych typów aktorów, co w przypadku living lab ${ }^{3}$, ale różniących się rolami. W literaturze dotyczącej living lab możemy spotkać się z różnymi rozważaniami dotyczącymi aktorów i ich ról [por. np. Cosgrave et al., 2013, Leminen, 2013; Leminen, Westerlund, 2017; Nyström et al., 2014]. Nyström z zespołem [2014] szczegółowo opisują różne podejścia do kształtowania się i wyznaczania ról w sieci, jaką jest living lab.

Biorąc pod uwagę koncepcje: quadruple helix [Carayannis, Campbell, 2009] oraz working regions [Clark, 2013], gdzie istotnymi aktorami są instytucje pośredniczące (intermediaries), jak np. agencje rozwoju, a także bazując na pracach autorów zajmujących się city lab [Nyström et al., 2014; Perjo et al., 2016; Scholl, Kemp; 2016; Westerlund, Leminen, 2011] możemy wymienić następujących uczestników tej platformy:

1. Władze publiczne (politycy i urzędnicy).

2. Przedsiębiorstwa (zróżnicowane względem wielkości i obszaru działalności, w zależności od zadania rozwiązywanego w ramach city lab).

3. Użytkownicy/mieszkańcy miasta (osoby indywidualne lub zrzeszone $w$ formalnych i nieformalnych organizacjach, np. NGO, ruchy miejskie).

4. Jednostki naukowe.

5. Instytucje pośredniczące.

Bazując na powyższych rozważaniach i wskazanej literaturze, a jednocześnie wykorzystując propozycję J. K. Benson [1983], przyporządkowującą poszczególnych aktorów funkcjonujących w ramach sieci do jednej z pięciu grup, spróbujmy wskazać uczestników living lab i city lab oraz przypisać im funkcje (patrz: tabela 1) ${ }^{4}$.

Szerzej o living lab patrz np. [World Bank, 2014].

Należy zastrzec, że to rozróżnienie dokonano dla skrajnych przypadków - przykładowo living lab mogą zakładać osiągnięcie celu społecznego, niezwiązanego z egoistycznymi
Living lab znacząco różni się od city lab. W tym pierwszym przypadku koordynatorem działań („zleceniodawcą”) jest przedsiębiorstwo, w drugim - władze miasta. Dostawcą rozwiązań („pomysłodawcą”, "kreatorem”) są odpowiednio użytkownicy: dóbr i miasta. W obu przypadkach w działaniach tych, oprócz użytkowników, władz publicznych i przedsiębiorstw, uczestniczą jeszcze, choć w różnym zakresie, jednostki naukowe i instytucje pośredniczące. W zależności od rodzaju zadania, jeden z wymienionych typów podmiotów może przyjąć rolę zarządzającego pracami. W przypadku living lab odbiorcą prac jest zlecające przedsiębiorstwo, a docelowo - użytkownicy dobra, gdy w city lab są to odpowiednio: władze publiczne i użytkownicy miasta. Funkcje living lab wpisują się w ekonomiczne cele przedsiębiorstwa: maksymalizację zysku i minimalizację strat (czyli celów prywatnych), podczas gdy w city lab chodzi o wkład w długookresowe planowanie rozwoju miasta (cel społeczny). W living lab wykorzystujemy prywatne zasoby przedsiębiorstwa i użytkowników dóbr oraz społeczne grupy podmiotów pracujących nad rozwiązaniem problemu, podczas gdy w city lab oprócz nich angażowane są zasoby władz publicznych. W obu przypadkach do rozwiązania problemu wykorzystuje się narzędzia komunikacyjne, z tym że w city lab są one ograniczone w związku z koniecznością zachowania kryterium legalności i racjonalności wypracowanego rozwiązania. Miarą sukcesu w living lab będzie wprowadzenie uzgodnionego wspólnie rozwiązania na rynek, podczas gdy w city lab chodzi o polepszenie jakości życia mieszkańców.

Znając już istotę city lab, aktorów i funkcje, a także dystynkcję względem pojęcia living lab, warto odwołać się do przykładu.

oczekiwaniami przedsiębiorstwa, który przyczyni się do polepszenia jakości życia. Zestawienie to ukazano w celu uwypuklenia różnic w sytuacji modelowej, z którą w idealnej postaci mamy do czynienia relatywnie rzadko. 


\section{Tabela 1. Living lab a city lab - cechy charakterystyczne}

\begin{tabular}{|c|c|c|}
\hline Charakterystyka lab & Living lab & City lab \\
\hline Koordynator & Przedsiębiorstwo & Władze miejskie \\
\hline Podmiot zarządzający & $\begin{array}{l}\text { W zależności od zadania - władze publiczne, } \\
\text { przedsiębiorstwa, użytkownicy/mieszkańcy } \\
\text { miasta, jednostki naukowe lub instytucje } \\
\text { pośredniczące }\end{array}$ & $\begin{array}{l}\text { W zależności od zadania - władze publiczne, } \\
\text { przedsiębiorstwa, użytkownicy/mieszkańcy } \\
\text { miasta, jednostki naukowe lub instytucje } \\
\text { pośredniczące }\end{array}$ \\
\hline Dostawca rozwiązań & Użytkownicy dóbr & Użytkownicy miasta \\
\hline Podmioty wspierające & $\begin{array}{l}\text { Jednostki naukowe, władze publiczne, instytucje } \\
\text { pośredniczące }\end{array}$ & $\begin{array}{l}\text { Jednostki naukowe, przedsiębiorstwa, instytucje } \\
\text { pośredniczące }\end{array}$ \\
\hline Odbiorca & $\begin{array}{l}\text { - Bezpośredni: przedsiębiorstwo } \\
\text { - Pośredni: użytkownicy dobra }\end{array}$ & $\begin{array}{l}\text { - Bezpośredni: władze miasta } \\
\text { - Pośredni: użytkownicy miasta }\end{array}$ \\
\hline Funkcja głównego aktora & $\begin{array}{l}\text { Przedsiębiorstwo - maksymalizacja zysku/ } \\
\text { minimalizacja strat }\end{array}$ & $\begin{array}{l}\text { Władze miasta: } \\
\text { - sterowanie procesem długookresowego pla- } \\
\text { nowania rozwoju miasta, w tym dostarczania } \\
\text { zasobów i wyznaczanie ram } \\
\text { - możliwość blokowania rozwiązań niespełniają- } \\
\text { cych kryterium realności i legalności }\end{array}$ \\
\hline Funkcje lab & $\begin{array}{l}\text { Prywatne - realizacja celu przedsiębiorstwa, } \\
\text { przy wykorzystaniu wiedzy użytkowników dóbr }\end{array}$ & $\begin{array}{l}\text { Społeczne - realizacja celu społecznego - polep- } \\
\text { szenie jakości życia użytkowników miasta }\end{array}$ \\
\hline $\begin{array}{l}\text { Rodzaj wykorzystywanych } \\
\text { zasobów }\end{array}$ & Prywatne, społeczne & Publiczne, prywatne, społeczne \\
\hline Podstawowe narzędzia & Komunikacja między uczestnikami & $\begin{array}{l}\text { Komunikacja między uczestnikami, z pewnymi } \\
\text { ograniczeniami wynikającymi z konieczności } \\
\text { zachowania kryterium legalności i realności }\end{array}$ \\
\hline Miara sukcesu & $\begin{array}{l}\text { Wprowadzenie na rynek wypracowanego w dro- } \\
\text { dze konsensu rozwiązania (dobra) }\end{array}$ & $\begin{array}{l}\text { Polepszenie jakości życia użytkowników miasta } \\
\text { poprzez wdrożenie w mieście, wypracowanego } \\
\text { w drodze konsensu, realnego i zgodnego z pra- } \\
\text { wem rozwiązania }\end{array}$ \\
\hline
\end{tabular}

Źródło: opracowanie własne.

\section{Studium przypadku - „Superścieżka” w Krakowie}

Władze Krakowa, odczuwając skutki kryzysu 2007/08, sprzedały fragment terenu zielonego w centrum z możliwością zabudowy biurowej. Po kilku latach przystąpiono do budowy biurowca, co spotkało się z niezadowoleniem niektórych mieszkańców miasta. Jako swoistą rekompensatę deweloper zaproponował zaprojektowanie pasa zieleni i wypoczynku między ruchliwq ulica a biurowcami, z możliwościq włączenia do projektu przyległych obszarów (łącznie ok. 5 ha). Tak powstał pomysł "Superścieżki", czyli pierwszego w Krakowie projektu rewitalizacji obszaru zlokalizowanego na gruntach miejskich i prywatnych, w odpowiedzi na potrzeby lokalnej społeczności ${ }^{5}$, inspirowanego popularnq od kilku lat koncepcja 'smart city'.

Prace planistyczne rozpoczęły się w 2015 r. od szerokich konsultacji i warsztatów z udziałem: mieszkańców, firmy deweloperskiej, firm architektonicznych, władz miasta, organizacji pozarządowych, a także urbanistów i pracowników naukowych. W pierwszej fazie mieszkańcy mogli zgłaszać swoje pomysły przy pomocy i współudziale pozostałych podmiotów. Pomysły

\footnotetext{
Portal Magiczny Krakow, http://krakow.pl/aktualnosci/207838,29,komunikat,supersciezka__ruszyly_prace_budowlane_na_skwerze_eilego.html (dostęp: 15.12.2018).
} 
te zostały poddane ocenie duńskiego urbanisty i architekta Jana Gehla. W dalszej części mieszkańcy poprzez głosowanie wybierali najlepszy projekt, który jest obecnie realizowany. Według stanu na grudzień 2018 r. z budżetu dewelopera zrealizowano dotychczas jedynie jeden fragment w pobliżu powstałego biurowca (w 2017 r. zrewitalizowano skwer im. M. Eilego). Kolejne mają być realizowane po osiągnięciu porozumienia z dysponentami gruntów, przy okazji innych inwestycji i po pozyskaniu finansowania.

Bazując na powyższym przykładzie możemy powiedzieć, że „Superścieżka” nosi znamiona city lab: pomysł zaistniał w odpowiedzi na zapotrzebowanie społeczne (spędzanie czasu wolnego), przy powstawaniu koncepcji mieliśmy do czynienia ze współpracą różnych podmiotów (jest to więc zarazem innowacja społeczna), a funkcję koordynatora działań pełniły władze miasta. O ile jednak na etapie projektowania możemy mówić o modelowym współdziałaniu, to zarazem jest to przykład city lab, którego założenia udało się dotychczas wdrożyć jedynie częściowo, na niewielkim fragmencie planowanego obszaru. Póki co nie jest znany kompleksowy plan działania i finansowania dalszych etapów "Superścieżki”. Prezentowany przykład trudno więc ocenić jednoznacznie jako sukces, choć należy podkreślić, że pierwszy etap inwestycji spotkał się z pozytywnym odbiorem mieszkańców Krakowa, zwłaszcza tych najmłodszych (plac zabaw).

\section{Związki city lab z innowacjami społecznymi - podsumowanie}

Bazując na powyższych rozważaniach warto zastanowić się nad związkiem pomiędzy innowacjami społecznymi a city lab. $\mathrm{Na}$ podstawie poczynionych rozważań zasadne wydają się być następujące charakterystyki tej formy współpracy:

1. Przedmiot działania: city lab to platforma do wdrażania innowacji społecznych (miejskich).
2. Cel działania: społeczny (publiczny) - rozwiązywanie fundamentalnych spraw związanych z długookresowym rozwojem i funkcjonowaniem miasta, jak np. wyznaczanie kierunków jego rozwoju, czy też dbanie o środowisko naturalne, a więc niekoniecznie tych służących wyłącznie osiąganiu zysku w rozumieniu pozytywnego wyniku finansowego.

3. Kluczowy udział aktorów społecznych użytkowników miasta: osób indywidualnych oraz formalnie i nieformalnie zrzeszonych grup.

4. Do fundamentów city lab zalicza się współuczestniczenie i współdecydowanie o rozwoju miasta, to ostatnie jednak przy ograniczeniach związanych z realnością i legalnością proponowanych innowacji (veto power władz miasta).

Reasumując wydaje się, że city lab jest interesującą propozycją wdrażania innowacji społecznych (miejskich), przy wydatnym udziale użytkowników miasta, uwzględniającym istotne funkcje władz lokalnych, którymi są pilnowanie realności i legalności powstających rozwiązań. Pełny sukces platformy city lab jako swoistego nośnika innowacji społecznych można jednak ogłaszać w przypadku, gdy zaprojektowane rozwiązanie zostanie w całości wdrożone, czego póki co nie można powiedzieć o prezentowanej w artykule "Superścieżce". 


\section{Literatura}

Almirall E. (2009). Understanding innovation as a collaborative, co-evolutionary process. Doctoral Thesis. Esade - Escuela superior de administracion y direccion de Emperas.

Benson J.K. (1983). "A Framework for Policy Analysis", w: D. Rogers, D. Whetten (eds.), Interorganisational Coordination: Theory, Research \& Implementation. lowa: lowa State University Press.

BEPA (2011). Empowering People, Driving Change. Social Innovation in the European Union. Luxembourg: Publications Office of the European Union.

Carayannis E.G., Campbell D.F.J. (2009). „'Mode 3' and 'Quadruple Helix': toward a 21st century fractal innovation ecosystem", International Journal of Technology Management, Vol. 46, No 3/4, s. 201-234.

Cosgrave E., Arbuthnot K., Tryfonas T. (2013). „Living Labs, Innovation Districts and Information Market places: A Systems Approach for Smart Cities", Procedia Computer Science, Vol. 16, pp. 668-677.

Clark J. (2013). Working Regions: Reconnecting Innovation and Production in the Knowledge Economy. London/New York: Routledge.

Kopyciński P. (2018). City lab as a platform for implementing urban innovation. The role of companies. 5th AIB-CEE Chapter Annual Conference Academy of International Business and Cracow University of Economics Krakow, 13st September.

Leminen S. (2013). "Coordination and Participation in Living Lab Networks", Technology Innovation Management Review, November, s. 5-14.

Leminen S., Westerlund M. (2017). "Categorization of Innovation Tools in Living Labs", Technology Innovation Management Review, January, Vol. 7, Iss. 1, s. $15-25$.

Moroń D., Klimowicz M. (2015). „Podmioty ekonomii społecznej w procesie zarządzania innowacjami społecznymi, Ekonomia Społeczna, nr 1, s. 21-37, DOI: 10.15678/ES.2015.1.02.

Mulgan G. (2012), „Social innovation theories: can theory catch up with practice", w: H.-W. Franz, J. Hochgerner, J. Howaldt (eds.), Challenge social innovation: potentials for business, social entrepreneurship, welfare and civil society (s. 19-42). Heidelberg/ New York: Springer, Welfare and Civil Society.

Murray R., Caulier-Grice J., Mulgan G. (2010). The Open Book of Social Innovation. UK: NESTA.

Nyström A.G., Leminen S., Westerlund M., Kortelainen M. (2014). "Actor roles and role patterns influencing innovation in living labs", Industrial Marketing Management, nr 43, s. 483-495.

OECD (2008). Podręcznik Oslo. Paris: OECD\&EUROSTAT. OECD (2011). OECD Guidelines for Multinational Enterprises. Paris: OECD Publishing.

Paskaleva K. (2015). „E-governance as an enabler of the smart city", w: M. Deakin (ed.), Smart cities. Governing, modelling and analising the transition. Oxfordshire: Routledge.

Perjo L., Fredricsson Ch., Costa S.O. (2016). PublicPrivate-People Partnership in Urban Planning. Baltic Urban City Lab.

Portal Magiczny Kraków, http://krakow.pl (dostęp: 15.12.2018).

Scholl Ch., Kemp R. (2016). „City Labs as Vehicles for Innovation in Urban Planning Processes", Urban Planning, Vol. 1, Iss. 4, s. 89-102.

Schumpeter J. (1960). Teorie rozwoju gospodarczego. Warszawa: PWN.

The Young Foundation (2012). Social Innovation Overview. A deliverable of the project: "The theoretical, empirical and policy foundations for building social innovation in Europe (TEPSIE)", European Commission - 7th Framework Programme. Brussels: European Commission, DG Research.

Urb@exp Project, http://www.urbanexp.eu (dostęp: 15.08.2017).

Voytenko Y., McCormick K., Evans J., Schwila G. (2016). "Urban living labs for sustainability and low carbon cities in Europe: Towards a research agenda", Journal of Cleaner Production, vol. 123, s. 45-54.

Wiktorska-Święcicka A., Moroń D., Klimowicz M. (2015). Zarządzanie innowacjami społecznymi. Difin: Warszawa.

www.socialinnovation2011.eu (dostęp: 13.12.2012). World Bank \& European Network of Living Labs (2014). Citizen-Driven Innovation: A Guidebook for City Mayors and Public Administrators. Brussels: World Bank \& European Network of Living Labs.

\section{City lab as a way to implement social innovation in urban areas}

Summary: This article attempts to combine two issues: present for some time in the scientific discussion concept of social innovation with a topic that appeared relatively recently - city lab. The aim of the considerations is to show the essence of city lab in the context of implementing social innovations. For its implementation, the author made an analysis of the relevant literature on the subject. The article starts with a review of understanding of social innovations. Next, the essence of city lab is described, indicating the actors and their functions. Finally, the author points out the relationship between the title concepts. In the presented approach, the city lab is a platform for implementing social innovations. The latter relate to longterm urban development planning, implemented with the participation of various stakeholders, with the 
dominating role of the city users (residents) as the main innovators and local authorities, watching the reality and legality of the proposed solutions. The presented approach seems to be worth promoting both by representatives of science and public decision-makers.

Keywords: city lab, living lab, social innovation.

\section{Prawa autorskie i licencja / Copyright and License}

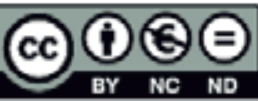

Artykuł opublikowano na licencji Creative Commons

Uznanie autorstwa - Użycie niekomercyjne - Bez utworów zależnych 3.0 Polska

http://creativecommons.org/licenses/by-nc-nd/3.0/pl/

This article is published under the terms of the Creative Commons

Attribution - NonCommercial - NoDerivs (CC BY-NGND 3.0) License

http://creativecommons.org/licenses/by-nc-nd/3.0/ 